\title{
Consensual Constitution-Writing Over Consensus Institutions: The Power of Inclusion through Group Rights in Mitigating Conflict
}

By Todd A. Eisenstadt (eisensta@american.edu), Tofigh Maboudi, and Ifeoluwa Olawole Paper presented at the American Political Science Association Annual Conference September 9, 2020

\section{DRAFT ONLY - CITE ONLY WITH AUTHOR PERMISSION PLEASE}

\begin{abstract}
The decades-long debate about whether power sharing (consensus) governments or majoritarianism diminish conflict may be missing an even more important element in diminishing conflict, whether all major groups participate in negotiations. Using crucial moments in a regime's history, the drafting and implementation of new constitutions, this article offers evidence that whether constitution-making processes include all relevant societal groups matters more in diminishing internal nation-state conflict than whether the resulting text constructs power-sharing institutions or majoritarian ones. After establishing this statistical pattern, we conduct further analysis showing that the mechanism of group rights establishment is at least partially responsible; that is, the inclusion of opposition groups in constitution drafting tends to produce group rights language. Such group rights language, which is not associated with power-sharing nor majoritarian institutions, strongly predicts diminishment of conflict after promulgation of the new constitution. We explore the implications of this finding for the literature on conflict diminishment, which may need to refocus from the type of institutions crafted to the procedural issue of who contributes to the crafting.
\end{abstract}


As violent conflict and democratic backsliding have both grown more frequent over the last couple of decades, the most common prescribed solution in the literature on political institutions has been the adoption of power-sharing arrangements. Some of the seemingly most intractable conflicts of the post-Cold War era have been addressed through such arrangements, including consociational institutions such as in Iraq 2005, Northern Ireland 1998, Kenya 2009, Lebanon (several occasions starting in 1943) and South Africa 1994. But in addition to its successes, attempts to negotiate power-sharing constitutions have failed lethally in Libya, South Sudan, and Yemen, over the last decade, claiming hundreds of thousands of lives. Does the construction of consociational (or "majoritarian-limiting") institutions via the creation of new constitutions lead to a diminishment of conflict? Our short answer, based on "before and after" assessments of social, ethnic and civil conflict in 195 constitution-making moments in 118 countries between 1974 and 2015 is that inclusion of such institutions does not diminish conflict, at least not directly. Indeed, the process of constitution drafting matters more than the text of the constitution that is drafted. Our deductive results, based on an extensive data set and conclusive statistical tests, contradict "conventional wisdom" inductive case studies.

Power-sharing gained cachet among policy practitioners in the 1990s after Belgian political scientist Arend Lijphart popularized it starting in the 1970s as consociationalism, parting from a study of his own country. The basic idea had an intuitive normative appeal; that including conflict "losers" in negotiating the new rules of the game, such as in moments of constitutional founding, would better serve the interests of former regime opponents and the rest of society. A slew of consultants applied this institutional design, particularly in Africa and the Middle East, into the $21^{\text {st }}$ Century. Deductive literature on the logic of power-sharing and the 
incorporation of that logic into designing parliaments, electoral systems, party systems, and federalism, was complemented by more idiosyncratic case studies arguing for approaches to coaxing former opponents into new regimes, which was frequently consistent with powersharing approaches. However, a counter-argument against power-sharing also emerged, claiming that by fixing quotas of power for all groups at the constitutional founding, constitution-crafters were in fact establishing static political systems, where quotas of power discouraged negotiations, rather than the flexibility needed to solve extant political problems as well as allow for changes in power structures and social contexts. The critics of power-sharing established their own argument for majoritarian political systems replete with their own institutional logic.

This article seeks to redirect the argument between these two positions, asserting that the argument may place an excessive emphasis on the form institutions take rather than who makes them. A small literature over how best to design post-conflict constitutions to diminish conflicts has emerged, although it has focused on particular cases rather than on broader tendencies. A related literature argues whether inclusion and/or participation in constitution-making improves levels of democracy. But our work, using levels of conflict before and after constitution-making, makes a deductive argument with data from all 195 new constitutions between 1974 and 2015, that inclusion diminishes conflict, while the form of institutional arrangements - whether powersharing or majoritarian - is not a statistically significant predictor of levels of conflict.

But do the institutions specified by constitutions really not matter? We show, in the second part of our argument, that inclusive constitutions mitigate conflict by establishing group rights provisions in constitutions. These provisions are not more likely in power sharing nor majoritarian governments, but they are more likely in constitutions which do include a wider range of interests in their negotiation. We specify the mechanism through which institutions 
specified in constitutions do matter, the inclusion of group rights. We show that the inclusion of all relevant groups, including regime opponents, in the negotiation of constitution drafts increases the likelihood that provisions for group rights will be included in constitutions. The inclusion of those group rights diminishes conflict.

In the next section we summarize the extant literature, arguing that debates about the impact of the form institutions on level of conflict and the role of process in constitution-writing follow parallel paths, but do not intersect. We summarize the few studies which directly assess the role of new constitutions on conflict, mostly using case study anecdotal evidence. After reviewing the debate at the theoretical and empirical levels, we construct an argument pitting majoritarian and consociational institutions against process variables but based on inclusion of groups in constitution-making rather than incentives for cooperation (which are hard to measure systematically) or statecraft considerations (such as incrementalism). We then discuss construction of our data set of conflict and constitution-making, the institutions and inclusion hypotheses, and the results of our analysis. We find that if relevant societal groups are included in negotiations from the beginning, then conflict is diminished after constitutional promulgation, whereas the effect of institutions - majoritarian or consociational - is indeterminant. Then, using structural equation modeling, we demonstrate that group rights serve as the mechanism through which inclusive new constitutions diminish conflict. We illustrate this mechanism with a few examples and conclude with implications of these findings for studies of institutional design.

\section{Non-intersecting Literatures on Institutions, Political Process, and Conflict Diminishment}

Following Lijphart (1977, 2012), several influential scholars (Hartzell and Hoddie 2015, Linz 1990, Norris 2008, to name a few) have argued in favor of power-sharing to diminish conflict. Lijphart laid out ten inductively derived characteristics of power-sharing governments (2012, 33- 
40). Among these, adoption of proportional representation in the electoral system, multiparty systems, parliamentary "grand coalitions" where ministries are split among ruling parties, minority vetoes over a range of issues, and federalism may be the most salient. Lijphart's theory has been applied - with differing degrees of orthodoxy - to India (Lijphart 1996, Wilkinson 2000), Iraq (McGarry and O'Leary 2007; Younis 2011), Lebanon (Salamey 2009), Northern Ireland (McGarry and O'Leary 2004), South Africa (Keobeble and Reynolds 1996, Sisk 2017), and in some cases, the diminishment of conflict lent credence to the intuitively credible theory.

While consociational power-sharing has arguably worked well in some cases, such as relatively homogenous Belgium and Switzerland, and in religiously diverse Northern Ireland and ethnically diverse Kenya, it has failed to diminish conflict at moments of constitution-making in other cases such as Iraq 2005, and even more violently in cases where exclusionary constitutions were never even able to get past the drafting room, such as in Libya 2012, South Sudan 2011, and Yemen 2015. Scholars like Horowitz $(1985,1991)$ and Reilly (2002) have directly challenged Lijphart, whose ideal type of consociational power sharing was based on induction. And scholars like Tull and Mehler (2005) Sriram and Zahar (2010), and Selway and Templeton (2012) have critiqued on empirical grounds in the Middle East and Africa. The broad form of the argument, made by Encarnacion (2005) is that by "freezing" political cleavages in place, power sharing has discouraged dialog and compromise.

The debate between consociational power-sharing and majoritarianism has been inconclusive, even in perhaps the most recent chapter, a rigorous study by Graham, Miller and Strom (2017) on the effects of power-sharing institutions on democratic survival. The authors found that what they called "constraining" power-sharing (institutions like the Bill of Rights and judicial review to preserve the rights of citizens) did improve democratic endurance, whereas 
inclusive power-sharing (such as minority rights and "grand coalitions") and dispersive powersharing (such as federalism) do not improve rates of survival of democracies. One of the only comprehensive Large $N$ tests of power-sharing, the Graham et al. study concludes that powersharing only promotes democratic survival in one of their three categories, and in the single category which really is not endemic only to power-sharing systems.

Parallel, but mostly not intersecting this work on institutional determinants of conflict diminishment, a few recent studies explore whether constitutional process can (at least indirectly) diminish conflict. For example, Carey (2009) and Ginsburg, Elkins, and Blount (2009) found strong and positive impact of group inclusion in constitution-making on democratization. However, these studies focused on the impact of constitutional processes on democracy measures, rather than the direct impact on conflict. Similarly, the influence of public participation in constitution making is the subject of a growing debate in recent scholarship of comparative constitution making. While many scholars support the incorporation of public participation in post-conflict constitutional drafting (Wing 2008, Widner 2008) many others have argued against it (Horowitz 2013, Saati 2015, and Brown 2017).

This growing literature has suggested a range of inductive approaches to solving societal conflict through constitution-writing. Lerner (2011) affirms the extremely political nature of constitution-writing and argues for incremental constitutional drafting, debate and implementation as a means of consciously defusing conflicts. Others, like Miller (2010) have emphasized that some cases have involved international allies and have tried to embed peacemaking in constitution-writing. While that may work for a small subset of cases experiencing severe conflict, the other issue raised by Miller, Wallis (2014), Eisenstadt, LeVan and Maboudi (2017), and Widner (2008) is that public participation in the constitutional process 
matters as this, to paraphrase Wallis, is how state institutions are legitimized, and, paraphrasing Widner, gain accountability. Other studies have also shown that public participation enhances the protection of rights for minorities (Fruhstorfer and Hudson 2019), although this impact is contingent upon the existence of some institutions such as party strength (Hudson 2019). And while this sounds quite logical and may apply in the most dramatic cases, we argue in this article that what matters most for diminishing levels of conflict is not the degree of public participation (measured as “strength in numbers"), but rather that all groups representing sizable portions of the public participate in constitution-drafting negotiations from the outset.

We seek to combine these disparate arguments regarding constitutions and conflict. In the section that follows, we counter-pose institutional design against constitutional process, operationalizing both hypotheses. After explaining the derivation of our independent variables and the "change in conflict after new constitutions" dependent variable, we explain our results.

\section{Hypothesizing the Effects of Institutional Design and Constitutional Process}

Whatever the motivations of the incumbent government for allowing the drafting of a new constitution, it would seem they would in many cases be motivated not to allow regime opponents to participate in that process as they might lose control of the resulting text. Hence, the real test of any regime's will to reform is whether they allow these opponents to sit at the table. Consociational or power-sharing governments require such participation in government, precisely, according to the argument, to guarantee opposition stakes in the new system. Building on these studies, we raise two contrasting hypotheses, on power-sharing and on inclusion.

H1 (Power-sharing): Constitutions which provide for power sharing institutions are more likely to diminish conflict than constitutions without such institutions. 
H2 (Inclusion): Constitutions drafted via inclusive processes are more likely diminish conflict than non-inclusive constitutions.

Our Power-sharing Hypothesis speaks to theories of power-sharing from Lijphart 1977 to Gates et al. 2016 and beyond. Corroborating the first hypothesis would validate arguments that power-sharing institutions do in fact diminish conflict. Our second hypothesis, by contrast, addresses procedural aspects of constitution-making, rather than the substance of the text itself. The Inclusion Hypothesis stems from claims that inclusion and/or participation in constitutionmaking improves the ability of new constitutions to diminish conflict (Widner 2008, Wing 2008), improve levels of democracy (Eisenstadt and Maboudi 2019, Horowitz 2013).

\section{Data and Analysis}

To test these hypotheses, we utilize several existing data sets. We present our empirical analysis in two stages. In the first stage, we test whether power-sharing institutions and/or the process of constitutional negotiations have any impact on political conflict. We particularly focus on constitutional moments to revisit whether power-sharing institutions diminish conflict but consider a counterargument that the process of constitutional founding matters more than the institutions designed in the parchment. We distinguish between individual participation and group inclusion in constitution-making processes across 195 national constitutions that have been promulgated in 118 countries from 1974 to 2015 . The starting point is 1974 to cover the entire Third Wave of Democracy. Before the Third Wave, participatory constitution making was a rare practice, but since then public participation in constitutional processes has increasingly become a democratic norm, even - to some extent - in hybrid and even authoritarian regimes. 
Upon showing that inclusion of all relevant groups in constitutional processes is more likely to reduce conflict than the alternative predictors, we show, in the second stage of our empirical analysis, the mechanism through inclusion diminishes conflict. That mechanism is the establishment of group rights. In other words, we show that inclusive bargaining in the constitutional process tends to produce strong group rights which tends to diminish conflict after promulgation. Before elaborating each of these causal arguments and then linking them, we first discuss how we measure conflict (as our outcome), power-sharing, and inclusion. Then, we describe our measures of group rights as well as different control variables.

\section{Measuring Conflict}

We use the weighted conflict index from Banks and Wilson's (2016) Cross-National Time-Series Data Archive for our measure of conflict. ${ }^{1}$ This index estimates all major social, ethnic and civil conflict including assassinations (a politically motivated attempted murder of a high government official or politician), strikes (involving at least 1,000 workers that is aimed at national government policies or authority), and guerrilla warfare (armed activity, sabotage, or bombings carried on by independent bands of citizens or irregular forces and aimed at the overthrow of the present regime), government crises (rapidly developing situations that threaten to topple regimes - excluding revolts aimed at such overthrows), purges (systematic elimination by jailing or execution of political opponents within regimes or their oppositions), riots (violent demonstrations or clashes of more than 100 citizens involving physical force), revolutions

\footnotetext{
${ }^{1}$ A major caveat with the Banks and Wilson's weighted conflict index is that it combines different forms of political conflict and peaceful forms of political participation (as in demonstrations or strikes) to armed forms of political violence (as in guerrilla warfare or political assassinations). However, by weighting these different forms of conflict, Banks and Wilson account for their different magnitudes, and might still offer a better and a more comprehensive data than other alternatives such as Correlates of War which mostly deals with different forms of inter-state war. Another common metric for measuring conflict is the Uppsala Conflict Data Program (UCDP) which dates back only to only 1989. Using this data would have provided values for only 41 percent of our observations.
} 
(successful or not), and anti-government demonstrations (peaceful public gatherings of at least 100 people to display or voice opposition to government policies or authority). The weighted conflict index weights assassinations by 24 , general strikes by 43 , guerrilla warfare by 46 , government crises by 48 , purges by 86 , riots by 102 , revolutions by 148 , and anti-government demonstrations by 200 . The sum of these eight weighted variables is then multiplied by 100 and divided by 8 . We collected the weighted conflict index data for three years before the new constitution's approval and three years after this. ${ }^{2}$ Our Conflict Change variable shows the difference in weighted conflict index from the three-year average before the new constitution and the three-year average after the new constitution.

\section{Operationalizing Power-sharing Institutions}

To measure power-sharing institutions, we used several measures chosen for representation of components of power-sharing and for being readily available in a maximum number of cases. A recent study identifies three distinct forms of power sharing, including inclusive, dispersive, and constraining power sharing and uses a total of 19 indicators (Graham et al. 2017) to measure these three forms of power sharing. To these authors, inclusive power sharing includes "arrangements that mandate the participation of several parties or groups in particular offices or decision-making processes." Dispersive power sharing includes "arrangements that divide authority among actors in a well-defined pattern (e.g., territorial decentralization)." And finally, constraining power sharing includes those "arrangements that limit the power of any actor and

\footnotetext{
${ }^{2}$ According to Ginsburg et al. (2009) the average length of constitution-making processes is 16 months (with a 22month standard deviation). In other words, 95 percent of constitution-making processes take approximately three years. Hence, we use a three-year time frame in our measure of conflict (and other select variables) before and after constitution promulgation to cover the time frame of each case.
} 
thus protect ordinary citizens and vulnerable groups against encroachment and abuse" (Graham et al. 2017, 688-89).

While this is perhaps the most comprehensive data on power sharing arrangements, it focuses heavily on de jure power sharing rules rather than de facto practices. Furthermore, the authors offer a dozen measures of these types of power sharing, whereas our objectives are more modest; we need only to identify some of the most representative broad indicators of powersharing and to compare these substantive mentions in constitutions to the procedural hypothesis to see which better explains whether and how new constitutions diminish conflict. Hence, we operationalize power sharing using three separate indicators based on both de jure constitutional provisions (from Comparative Constitutional Project data set) and de facto power sharing practices (from the V-Dem data set). Our three power sharing indicators include Egalitarian Democracy Index, Clean Elections Index, and Federalism.

The Egalitarian Democracy Index is a V-Dem (Coppedge et al. 2017, 54) component of democracy which shows the degree to which "rights and freedoms of individuals are protected equally across all social groups, ...resources are distributed equally across all social groups, ...[and] groups and individuals enjoy equal access to power.” In other words, this is a broad measure of the extent to which democracy in a given nation embodies ideals of power-sharing and rights of minorities. The Clean Elections Index, another V-Dem indicator, shows the degree to which elections are free and fair. While not restricted to power-sharing democracies (as opposed to other forms), this is a measure of how readily groups share power through elections. As such, it "connotes an absence of registration fraud, systematic irregularities, government intimidation of the opposition, vote buying, and election violence" (Coppedge et al. 2017, 59). These two variables are measured as averages of three years before the constitution. Our last 
indicator is from Elkins et al.'s (2014) Comparative Constitutional Project (CCP) dataset which codes the content of all national constitutions from 1789 to 2013. Federalism is a dummy variable identified by Lijphart onward as an indicator of power-sharing, showing whether the state is described as federal in the constitution. These three indicators do each fit a separate dimension of Graham et al.'s three power sharing types. While Egalitarian Democracy Index fits their category of inclusive power sharing, Federalism is a dispersive power sharing, and Free Elections Index is a proxy for arrangements that "limit the power of any actor and thus protect ordinary citizens and vulnerable groups" (Graham et al. 2017, 689).

\section{Operationalizing Inclusion}

By inclusion, we mean whether major groups, such as all relevant political parties, blocs, and movements, interest groups, civil society organizations, as well as ethnic, religious, or linguistic groups, were included in different stages the constitutional reform process. A process is considered inclusive if all these groups are present and non-inclusive if major groups are systematically excluded. Thus, the Inclusion variable measures the degree to which different stages of the process (writing, deliberation, ratification) are representative of the broader society. For each stage, the level of inclusion is coded 0 (non-inclusive), 1 (mixed), or 2 (inclusive). As with the previous variable, we aggregated and recoded all three stages to create a binary Inclusion variable showing whether the process in general was inclusive (1) or not (0).

Measuring inclusion is difficult for several reasons. First, we need to determine which groups are considered "relevant" and "major" actors in each case. Second, we need to determine the degree to which these relevant and major groups and interests are allowed to meaningfully shape the constitutional outcome. We depended heavily on several available resources to first 
identify the major relevant groups and interests in each of our cases. ${ }^{3}$ We addressed the second challenge by "negatively" measuring exclusion. Extensive information is more readily available on "boycotts," "withdrawals," and other forms of exclusions or refusals to participate by major political and social group, than information on which groups were invited to participate.

We distinguish between self-exclusion and forced exclusion as two broad forms of noninclusive constitutional processes. Self-exclusion is when a group decides not to participate, although the authoritarians do not block such participation. This usually assumes the form of boycotts, voluntary participation withdrawal, and other forms of participation withholding. Voluntary exclusion may be strategic (often to press constituent assemblies by "withholding" legitimation of a process) or in protest (when participation seems "rigged" against getting desired results). While our data base captures both forms of exclusion, we emphasize the agency of opposition groups in self-exclusion.

In coding non-inclusion, we did not distinguish between scope and breadth of partial exclusion which may have existed in tandem with exclusion. Rather, when any of the enumerated conditions of non-inclusion existed, we counted them as non-inclusive, as differentiating exclusion causes was overly challenging. But even without coding self-inclusion, as in the April 6 Movement in Egypt, as distinct from authoritarian group exclusion (as in the Soviet Union 1977, Saudi Arabia 1992, and Somalia 2012), we achieved robust statistical findings. Many exclusionary processes were found to be non-inclusive because authoritarians logically did not want their challengers shaping constitutions. The majority of the 195

\footnotetext{
${ }^{3}$ The sources consulted include William S. Hein \& Company (2012), Widner (2004), Institute for Democracy and Electoral Assistance's Constitutionnet.org, Comparative Constitutions Project, Economist Intelligence Unit country reports, and the CIA World Fact Book, as well as peer reviewed area studies journals (for a few cases, such as Afghanistan or Somalia, which required additional research).
} 
constitutional processes in our data set experienced group exclusion in at least one of the stages of constitution-making process, whether self-exclusion or incumbent-led exclusion.

\section{Operationalizing Group Rights}

Group Rights have been conceptualized (and measured) differently in different fields of study. In studies of international law, group rights are mostly referred to the right of ethnic, religious, linguistic, and other minority groups within specific national boundaries (Lerner 2003). In political philosophy, two conception of groups right have emerged: the corporate (or traditional) conception and the collective conception. ${ }^{4}$ The corporate conception is that group rights are set of rights held by a group as a single unitary entity, and not by individual members of the group. In the collective conception, on the contrary, "group right is a right held jointly by those who make up the group" (Jones 1999, 85). In constitutional law studies, Law and Versteeg (2011) identify community/group rights as representing the third-generation of constitutional rights which, in their empirical manifestation, include rights for the elderly, those with special needs, women, children, families, consumers, minorities, victims of crime, prisoners, as well as affirmative action provisions related to any of these groups. Parallel to the corporate and collective conceptions in political philosophy, Banks $(2001,53)$ identifies group-based and individual-based collective rights. While the former includes rights held by trade unions, religious groups, and charitable organizations, for example, the latter are rights for individual members of groups such as people of color. Pogge $(1997,191)$, however, distinguishes among three different legal group rights. The first is "group rights proper" which are rights held by a group as a group. The second is "group-specific rights" which are "rights had only by members

\footnotetext{
${ }^{4}$ Contrary to Jones's (1999) usage of these terms, several scholars (see for example, McDonald 1991, Galenkamp 1993, Newman 2011) who developed the "corporate" conception of group rights use the term "collective" to describe those rights.
} 
of a certain group rather than by all." The third is "group-statistical rights" which are "rights that protect or enhance the aggregate status of the embers of a group.

Building on these different concepts of groups rights, we distinguish between what we call collective rights and group equality rights. Collective rights, which are similar to Banks' (2001) group-based rights, are those rights held by individual members of a group or organization collectively. Group equality rights, similar to Pogge’s (1997) group-statistical rights, are aimed at protecting minority groups in a society. To measure these group rights, we rely on the CCP dataset. First, we estimate a Collective Rights Index from five binary variables measuring whether the constitution guarantees: the right to form and join political parties, the right to form and join trade unions, the right to strike, freedom of assembly, and freedom of religion. The Collective Rights Index, as such, ranges from 0 (where the constitution does not provide for any of these five rights) to 5 (where the constitution includes all of them).

On average, constitutions promulgated between 1974 and 2015 include 4 out of 5 of these collective rights. In our dataset, only one constitution (South Africa, 1983) does not include any of these rights, while 56 constitutions have all of them. Second, we estimate a Group Equality Index from seven binary variables measuring whether the constitution protects groups from discrimination or provides for equality based on groups' nationality, race, language, religion, color, creed/beliefs, and tribe/clan. On average, constitutions promulgated between 1974 and 2015 include only three out of seven of these group equalities rights. In our dataset, 14 constitutions do not include any of these rights, while two constitutions (Rwanda 2003 and Zimbabwe 2013) have all of them. Finally, Our Group Rights Index is composed of all collective rights and group equality provisions. The variable ranges from 0 to 12 with a global average of 
seven rights. South Africa's 1983 constitution is the only constitution in our dataset which does not have any rights, while Rwanda's 2003 and Zimbabwe's 2013 documents include all of them.

\section{Majoritarianism, Presidentialism, and other Controls}

As we discussed above, several scholars have argued forcefully for the plurality-majoritarian solution for conflict management in ethnically divided societies. We consider this in our analysis using Head of State Selection variable from the CCP data set. Head of State Selection indicator categorizes the electoral system for the Head of State. We created a binary variable from these categories with 1 indicating a Majoritarian electoral system and 0 for any other electoral system. Next, several scholars have vigorously debated the merits of presidential regime types for democracy. The choice between presidential or parliamentary system has in theory been at the center of debates between power-sharing and majoritarian systems, and empirically has been at the center of heated debates between constitutional engineers in cases such as India. We control for presidentialism using a binary variable from Cruz, Keefer, and Scartascini's (2018) Database of Political Institutions (coded 1 for presidential systems).

We also control for public participation in constitution-making process. Participation entails the inclusion of individual citizens in the process (rather than the inclusion of groups). The Participation variable, as such, estimates the extent to which the general public is involved in different stages of constitution-making, from electing the constituent assembly member to voting in the constitutional referendum. Similar to Inclusion variable, we create a binary Participation variable showing whether the process in general was participatory (1) or not (0).

Next, ethnic division is considered as another predictor for both implementing power sharing institutions and increasing conflict (Horowitz 1985). We control for ethnic division by 
adding variable controls for ethnolinguistic fractionalization using Alesina et al.'s (2003) data. We also control for a country's level of development, broadly speaking, with natural log of Gross Domestic Product (GDP) per capita. We control for a country's size using a natural log of population. These last two variables are from the World Bank's World Development Indicators (2013). Finally, we control for time as measured by the year the constitution went into effect.

\section{First Stage Empirical Findings: Institutional Design versus Constitutional Process}

In the first stage of our empirical analysis, we test our two hypotheses using the variables specified above. We test whether overall increased inclusion and/or our institutional variables which include power sharing arrangements, majoritarianism controls, and presidentialism have an impact on change in conflict, from the three-year average before constitution promulgation to the three-year average after constitution promulgation. ${ }^{5}$ We use an OLS model to test our hypotheses. The general statistical model is:

$$
Y_{i}=\beta_{1} \text { Inclusion }_{i}+\beta_{2} \text { Powersharing }_{i}+\beta_{3} Z_{i}+\varepsilon_{\mathrm{i}}
$$

Where $Y_{i}$ is the dependent variable (change in conflict), and Powersharing ${ }_{i}$ and Inclusion $_{i}$ are the

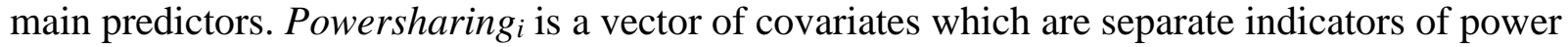
sharing, and $Z_{i}$ is a vector of control covariates including Participation, Majoritarianism, Presidentialism, Ethnolinguistic Fractionalization, GDP per capita, Population, and Year.

Table 1 below shows the OLS results for the impact of forms of constitution-making and various power sharing arrangements on change in conflict. As the table shows, there is a negative and statistically significant correlation between inclusion and change in conflict. In other words,

\footnotetext{
${ }^{5}$ The change in conflict term is measured in absolute value, and hence we do not pre-judge whether conflict diminishes or increases with the new constitution. This is a purely empirical question, although we frame it in terms of conflict reduction because this would be the normatively good result.
} 
inclusion of different societal groups and interests decreases conflict and that this relationship is statistically significant at conventional levels. The results show, however, that there is no statistically significant relationship between any of the power sharing institutions (including egalitarian democracy, clean elections, federalism, majoritarianism, and presidentialism) and change in conflict, indicating that none of these arrangements is a statistically significant predictor of post-constitutional change in conflict. Furthermore, the relationship between participation and conflict is positive but not statistically significant. Among our control variables, only population and year have statistically significant correlation with change in conflict. Population have negative and statistically significant correlations with change in conflict, indicating that populous nations are more likely to experience diminished conflict after constitution promulgation. Lastly, the results show that more recently adopted constitutions are more likely to result in increased conflict.

Table 1: The Impact of Constitutions and Power Sharing Institutions on Change in Conflict

\begin{tabular}{lc}
\hline & \\
VARIABLES & Change in Conflict \\
\hline & \\
Inclusion & $-2,480.32 * *$ \\
& $(1,217.36)$ \\
Participation & $1,454.47$ \\
Egalitarian Democracy Index & $(1,414.87)$ \\
Clean Elections Index & 898.05 \\
& $(2,382.87)$ \\
Federalism & $-4,647.40$ \\
Presidentialism & $(2,812.81)$ \\
& -524.50 \\
Head of State Selection (Majoritarian) & $(1,745.42)$ \\
& $1,220.67$ \\
Ethnolinguistic Fractionalization & $(1,558.53)$ \\
& $1,368.76$ \\
& $(945.86)$ \\
& $2,610.06$ \\
& $(1,948.03)$
\end{tabular}




\begin{tabular}{lc} 
GDP per capita $l n$ & -750.32 \\
& $(458.91)$ \\
Population $l n$ & $-522.66^{*}$ \\
& $(310.31)$ \\
Year & $186.64 * * *$ \\
& $(50.28)$ \\
Constant & $-362,296.83 * * *$ \\
& $(99,363.43)$ \\
Observations & 118 \\
R-squared & \\
\hline \multicolumn{3}{c}{ Standard errors in parentheses } \\
& $* * * \mathrm{p}<0.01, * * \mathrm{p}<0.05, * \mathrm{p}<0.1$ \\
\end{tabular}

Overall, the results in Table 1 provide strong evidence in support of our inclusion hypothesis, while we could not find sufficient evidence to support the power sharing hypothesis. Our empirical analysis shows that the inclusion of different societal groups, interests, and ideas early on during constitutional refounding moments matters for conflict even more than the designed power sharing institutions. The results show that presidentialism does not necessary increase conflict (and by extension, nor does parliamentarism decrease conflict), that federalism is not necessarily a predictor of diminished or increased conflict, that the choice between majoritarianism and plurality might not be not as important as previous works have argued. What matters is that different societal groups and interests are allowed to participate in shaping their constitution. In the next step, we try to explain the mechanism through which inclusion of different societal groups leads to diminished political conflict.

\section{Second Stage Empirical Results: Institutional Design versus Constitutional Process}

To show the causal effects of inclusion (and other predictors in our model) on conflict we use mediation analysis with Structural Equation Modeling (SEM). ${ }^{6}$ In our mediation analysis, we

\footnotetext{
${ }^{6}$ Mediation analysis was first addressed by Barron and Kenny (1986) and is very common in other social psychology studies.
} 
consider Group Rights as an intermediate variable (the mediator) which helps explain how or why inclusion impacts conflict. Mediation analysis in particular and SEM in general are powerful statistical tools which show the mechanism by which an intervention affects the response. Although SEM and regression models are very similar in appearance, they are fundamentally different in logic. Most importantly, in a regression model, a clear distinction exists between independent and dependent variables. In SEM, on the contrary, there is reciprocal relationship between the two, meaning that a dependent variable in one model equation can become the independent variable in other equations of the SEM system. As a result, rather than independent and dependent variables, SEM models use endogenous and exogenous variables. Endogenous variables refer to the outcome in at least one of the SEM equations and exogenous variables refer to all other variables in the study (Gunzler et al. 2013). In our SEM equations, Group Rights and Change in Conflict are the endogenous variables (outcomes) and all covariates and control variables are the exogenous variables.

Figure 1 shows a path diagram for the causal relationship between Inclusion or the intervention $\left(X_{i}\right)$, Group Rights or the mediator $\left(Z_{i}\right)$, and Diminished Conflict or the response $\left(Y_{i}\right)$. We use Group Rights as the mediator because mediation assumes both causality and a temporal ordering among the three variables under study (i.e. intervention, mediator and response). We argue that an inclusive constitution-making process is likely to increase the number group rights provisions in the constitution, and more constitutional group rights, in turn, will reduce the potentiality of inter-group conflicts three years after promulgation.

Figure 1: Path Diagram for the Causal Relationship

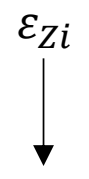




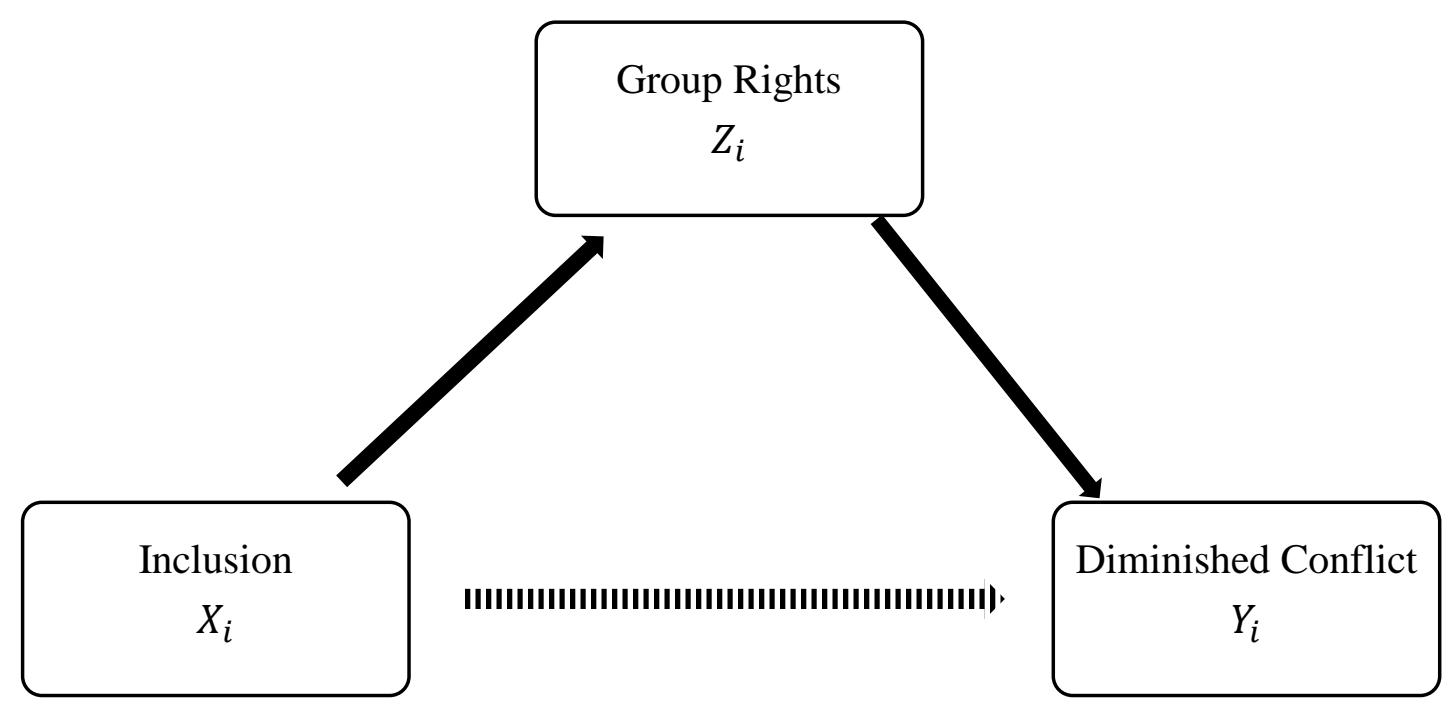

The SEM for this mediation model is given by:

$$
\begin{aligned}
& Z_{i}=\beta_{0}+\beta_{x z} x_{i}+\varepsilon_{z i} \\
& Y_{i}=\gamma_{0}+\gamma_{z y} z_{i}+\gamma_{x y} x_{i}+\varepsilon_{y i}
\end{aligned}
$$

The primary hypothesis in our mediation analysis is that the effect of intervention (Inclusion) on the response (Conflict) is mediated by a change in the mediating variable (Group Rights). In a full mediation process, the effect is fully mediated by the mediator. In other words, in the presence of the mediator, the pathway connecting the intervention to the outcome is completely broken so that the intervention has no statistically significant direct effect on the outcome. In practice, however, partial mediation is more common. In other words, even after the mediator is introduced in the model, the intervention can still have some residual direct (but statistically insignificant) effect on the outcome.

Table 2 shows the results for the model specified above. ${ }^{7}$ The first column shows the impact of our predictors on constitutional Group Rights and the second column shows the impact

\footnotetext{
${ }^{7}$ Results of the SEM model is similar to a two-stage OLS model.
} 
of the predictors on Change in Conflict after the mediator (Group Rights) is introduced in the model. As the results show, Inclusion has a positive and statistically significant relationship with Group Rights and Group Rights, in turn, has a negative and statistically significant correlation with Change in Conflict. Moreover, after the introduction of our mediator in the model (column 2), Inclusion has no statistically significant impact on Conflict. In other words, the impact of Inclusion is mediated through Group Rights. No other predictor in our study have the same pathology at a statistically significant level.

Table 2: SEM Mediation Analysis

\begin{tabular}{|c|c|c|}
\hline VARIABLES & $\begin{array}{c}\text { (1) } \\
\text { Group } \\
\text { Rights }\end{array}$ & $\begin{array}{c}(2) \\
\text { Change in } \\
\text { Conflict }\end{array}$ \\
\hline Group Rights & & $\begin{array}{c}-581.11 * * \\
(231.91)\end{array}$ \\
\hline Inclusion & $\begin{array}{c}1.47 * * * \\
(0.52)\end{array}$ & $\begin{array}{c}-1,582.54 \\
(1,268.57)\end{array}$ \\
\hline Participation & $\begin{array}{c}0.83 \\
(0.62)\end{array}$ & $\begin{array}{c}2,022.27 \\
(1,467.21)\end{array}$ \\
\hline Egalitarian Democracy Index & $\begin{array}{l}-0.06 \\
(0.98)\end{array}$ & $\begin{array}{c}551.81 \\
(2,299.88)\end{array}$ \\
\hline Clean Elections Index & $\begin{array}{l}-0.40 \\
(1.20)\end{array}$ & $\begin{array}{c}-4,162.94 \\
(2,804.26)\end{array}$ \\
\hline Federalism & $\begin{array}{l}-0.16 \\
(0.75)\end{array}$ & $\begin{array}{c}-416.64 \\
(1,752.15)\end{array}$ \\
\hline Head of State Selection (Majoritarian) & $\begin{array}{l}-0.07 \\
(0.41)\end{array}$ & $\begin{array}{l}1,222.62 \\
(963.53)\end{array}$ \\
\hline Presidentialism & $\begin{array}{c}0.19 \\
(0.64)\end{array}$ & $\begin{array}{c}1,405.76 \\
(1,493.41)\end{array}$ \\
\hline Ethnolinguistic Fractionalization & $\begin{array}{c}1.20 \\
(0.84)\end{array}$ & $\begin{array}{c}3,063.65 \\
(1,985.81)\end{array}$ \\
\hline GDP per capita $l n$ & $\begin{array}{l}-0.09 \\
(0.22)\end{array}$ & $\begin{array}{l}-982.24 * \\
(508.18)\end{array}$ \\
\hline Population $\ln$ & $\begin{array}{c}-0.30 * * \\
(0.14)\end{array}$ & $\begin{array}{c}-836.34 * * \\
(335.87)\end{array}$ \\
\hline
\end{tabular}




$$
\begin{array}{lcc}
\text { Year } & 0.05 * * & 238.83 * * * \\
& (0.02) & (51.50) \\
\text { Constant } & -96.39 * * & -456,347.70 * * * \\
& (42.09) & (101,095.05)
\end{array}
$$

Observations $102 \quad 102$

$$
\begin{aligned}
& \text { Standard errors in parentheses } \\
& * * * \mathrm{p}<0.01, * * \mathrm{p}<0.05, * \mathrm{p}<0.1
\end{aligned}
$$

Next, we calculate the total impact of Inclusion on Conflict by adding the direct impact and indirect impacts of Inclusion as specified in Table 2. In mediation analysis, the direct effect $\left(\gamma_{x y}\right)$ is the pathway from the intervention to the response while controlling for the mediator (the broken arrow in the Figure 1). The indirect effect $\left(\beta_{\mathrm{xz}}\right.$ and $\left.\gamma_{\mathrm{xy}}\right)$ is the pathway from the intervention to the response through the mediator (the solid arrows in Figure 1). The total effect is the sum of the direct and indirect effect $\left(\gamma_{x y}+\beta_{x z} \gamma_{x y}\right)$. In other words,

$$
(-1582.539)+\left[\left(1.473841^{* * *}\right) X\left(-581.1142^{* *}\right)\right]=-2439.009^{* *}
$$

We also calculate the total effect of other main predictors. As Table 3 shows with the exception of some of the control variables, none of the main predictors have a statistically significant total effect on Change in Conflict.

Table 3: Total Effect of Predictors on Change in Conflict

\begin{tabular}{lc}
\hline VARIABLES & $\begin{array}{c}\text { Total Effect on } \\
\text { Change in Conflict }\end{array}$ \\
\hline Inclusion & $-2439.01^{* *}$ \\
& $(1,258.70)$ \\
Participation & $1,541.48$ \\
Egalitarian Democracy Index & $(1,498.71)$ \\
Clean Elections Index & 587.29
\end{tabular}


$(2,887.69)$

Federalism

$-325.40$

$(1,804.88)$

Head of State Selection (Majoritarian) $\quad 1,261.46$

(992.62)

Presidentialism

$1,295.25$

$(1,538.02)$

Ethnolinguistic Fractionalization

$2,365.87$

$(2,025.8)$

GDP per capita $l n$

Population $l n$

$-664.39 * *$

Year

$207.42 * * *$

Observations
\[ \begin{array}{r}\text { Standard errors in parentheses } \\ * * * \mathrm{p}<0.01, * * \mathrm{p}<0.05, * \mathrm{p}<0.1\end{array} \]

In sum, the results of our statistical analyses show that inclusion of different interest and societal groups in constitutional negotiations have a significant impact on diminished conflict after constitutional promulgation. Our mediation analysis shows that the mechanism through which inclusion causes diminished conflict is through constitutional guarantees for equality and protection against discrimination for different societal groups. By being present at the constitutional negotiation table, interest groups can ensure that the constitution provides for equality and protects against discrimination and injustice beyond authoritarian window dressing.

\section{Exploring the Causal Mechanism: Illustrative Cases}

The empirical findings above show that there is a statistically significant relationship between inclusion during constitutional refounding moments and diminished conflict three years after constitutions. They do not necessary mean that all the constitutions diminish conflict. As Graph 1 
below shows, constitutions diminish conflict in 53 percent of the cases (93 out of 176 cases for which we have data on conflict), while increasing conflict in 30 percent of the cases (53 out of 176 cases) and having no impact on conflict in 17 percent of the cases (30 out of 176 cases).

\section{Graph 1: Constitutions and Conflict}

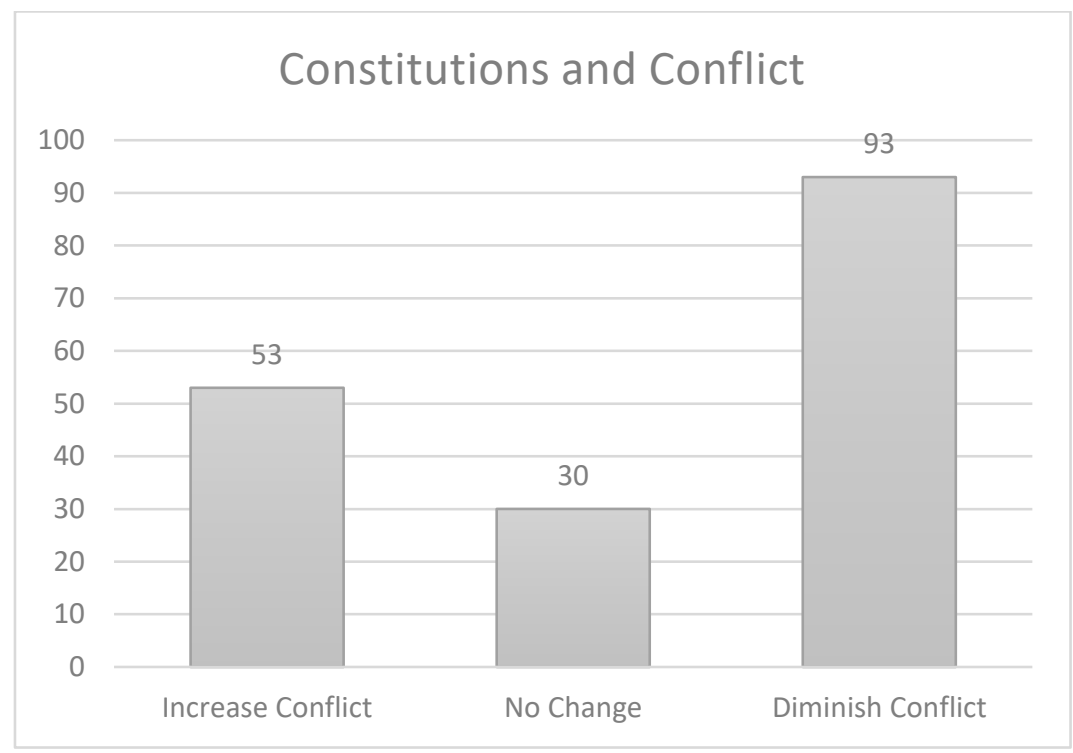

Even inclusion by itself is not a sufficient condition for conflict diminishment. Some noninclusive processes might also yield reduced conflict. However, as Figure 2 shows, in the 93 constitutional cases with diminished conflict, the impact of inclusive processes on decreasing conflict is almost four times higher than the impact of non-inclusive processes on change in conflict. We argue that the impact of inclusion of conflict is because inclusive processes are more likely to institutionalize group rights. Inclusive constitutional reform process, on average, result in more than 25 percent increase in constitutional provisions guaranteeing group rights. ${ }^{8}$ Two illustrative cases can show this causal mechanism.

\footnotetext{
${ }^{8}$ In our data, while non-inclusive processes result in constitutions with an average of six group rights provisions, inclusive processes yield an average of eight group rights provisions.
} 
Graph 2: Inclusion and Average Change in Conflict (for Cases with Diminished Conflict)

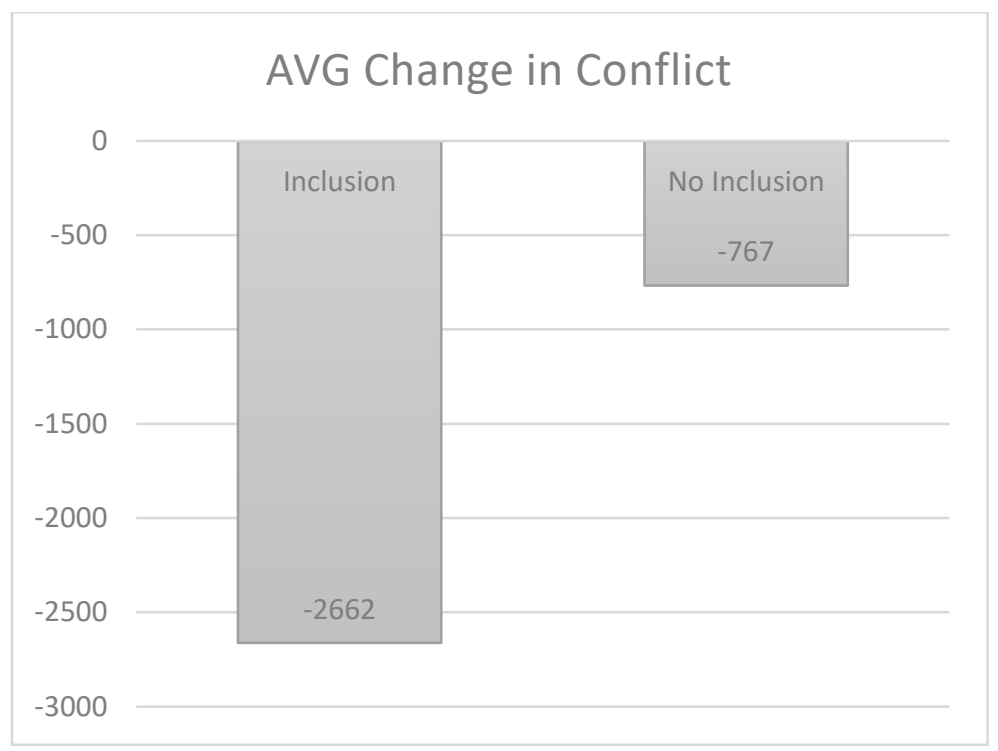

The effect of inclusion on levels of conflict, as mediated by the inclusion of group rights in new constitutions, is well indicated by Latin America's Andean "pink tide" cases, where leftist presidents such as Evo Morales in Bolivia and Rafael Correa in Ecuador extended group rights to indigenous people (and other citizens) as part of their constitutional reforms, instigated by at least partially open constituent assembly processes, which reduced conflict in the following years. Having experienced multiple expulsions of duly elected presidents at the turn of the $21^{\text {st }}$ Century, Ecuador held a constituent assembly in 2008, which was coded as inclusive (with a score of 6 on a $0-6$ scale). Multicultural group rights for indigenous people, who constituted some 30 percent of the population, were a centerpiece of the new Ecuadorian constitution (ranking among the 97 the power of inclusion through group rights percentile of all national constitutions with regard to the number of group rights), and the ethnic tensions which had felled two presidents and fomented extensive social movement activity prior to Correa's election diminished (Becker 2011). Former Constituent Assembly Chair Alberto Acosta (author interview 
2015) said that Correa imposed some selection of some 80 out of 130 members of that body, but that hundreds of citizens did venture to the historic town of Montecristi, Ecuador, where the assembly was held, and that the first six months of the process were pluralistic and inclusive, until the president rushed texts through the approval process during the assembly's final weeks.

In contrast with Ecuador's relative success as an inclusive process which diminished conflict through the mechanism of group rights introduction, Yemen represents the opposite of Ecuador, a case where low inclusion without group rights failed to generate a new constitution. In 2012, when Ali Abdullah Saleh, Yemen's president since the unification of the country in 1990, resigned after major protests erupted as a result of the Arab Spring revolutions around the Middle East and North Africa, the country seemed to be on a relatively peaceful and successful path toward democracy. However, intra-elite violence in Yemen soon overshadowed the wave of protests which favored democratic opening (Mujais, 2017). After violence broke out, in 2013, the United Nations sponsored a National Dialogue Conference (NDC). The NDC crafted an interim Constitution, concluding that Yemen should become a federal state (Williams, Sommadossi \& Mujais, 2017). The NDC created a Constitution Drafting Committee (CDC) with a transitional government including the former opposition bloc, the Joint Meeting Parties (JMP), a five-party alliance that included the leading Islamist party, Islah, as well as the Yemeni Socialist Party (YSP), the Nasirist Popular Unity party, and two small Zaydi parties (Alley, 2013). The CDC was made up of 17 panel members including lawyers, diplomats and other professionals representing Yemen's geographic, political, and ethnic diversity (Mujais, 2017). The CDC produced a final draft of the Constitution in January 2015, which was immediately opposed by several groups in both Northern and Southern regions. As a protest to the draft Constitution, the Shia Houthis in the North kidnapped the Chief of Staff, Ahmed Awad 
bin Mubarak, on his way to hand over the new constitution to the National government (Mujais, 2017). Shortly after, they surrounded the presidential palace, and forced President Hadi to resign, dragging Yemen into a still ongoing civil war. Constitutional bargains in Yemen, instead of being instruments for compromise, exacerbated the conflict. The Constitution was supposed to split Yemen into six federal regions but was never adopted as conflict broke out. The noninclusion of key groups, particularly Southern supporters in major decision-making during the writing of the Constitution, and the emphasis on federalism motivated the Houthi coup and takeover of Yemen (Mujais, 2017). While most cases represent more modest combinations of inclusion and conflict mitigation, Ecuador represents a moderately successful case of the pathway described above from inclusion to group rights to conflict mitigation, while Yemen represents abject failure in this regard, albeit with an important initial effort at inclusion.

These brief case studies are merely illustrative of the logic of how the group rights mechanism channels inclusion. While many other cases convey greater nuance as inclusion may succeed, but group rights may fail (37 percent of cases), or vice versa (40 percent of cases), we here present Ecuador as an example where both indications succeed (as in 48 percent of cases in our sample). And while our data set unit of observation is "constitution-years" which is based on only promulgated constitutions, it is worth noting that "near misses" in constitution-making, as in Yemen 2015, Libya 2017, and South Sudan 2011, did not make our data base, despite having the normatively adverse outcome of violence and civil war.

Indeed, despite power sharing arrangements and peace deals or agreements, the constitution still failed and resulted in increase in conflict within three years after the constitution was created. For instance, political transitions propelled by the Arab Spring devolved into civil wars that have resulted in over 5,800 deaths in Libya and over 10,000 deaths in Yemen (Johnson, 
2017). Within three years of gaining independence in 2011, South Sudan erupted into a civil war in 2013 that culminated from conflict between political factions, resulting in some 383,000 deaths and about two million displacements (Specia, 2018; Human Rights Watch, 2018). We certainly cannot prove that not following the pathway of inclusion and group rights led to increased violence, but the strong relationships established in our analysis lead us to speculate. We further clarify the logic of our argument in the conclusion and further establish the link between inclusion and group rights.

\section{Conclusions: Draft Inclusion-sharing May be the Best Indicator of Power-sharing}

The statistical results show strong empirical evidence in support of our inclusion hypothesis, while they do not provide robust evidence conferring our power sharing hypothesis. Our empirical analysis implies that the scholarly debates about presidentialism vs. parliamentarism, majoritarianism vs. proportional representation, and federalism vs. unitary governments may be exaggerated. After all, presidential systems do not seem to increase conflict or regime crisis, federalism is not a strong predictor of diminished conflict, and the choice between majoritarianism and plurality is not as important as previous works have suggested. It is instructive that despite decades of discussion regarding this critical research area of comparative political institutions, that, despite the parsimony and logic of Lijphart's argument, it has not been strongly confirmed, and in fact, has been challenged by strongly reasoned opposition led by scholars like Horowitz (1985) and Reilly (2002).

Constitutions have been viewed as a crucial moment to allow nations to move forward after internal conflicts, and also as moments for expressing "good faith" to resolve issues within broader frameworks of conflict. Recall that a range of inductive approaches to solving societal conflict through constitution-writing has been suggested. Lerner (2011) affirms the extremely 
political nature of constitution-writing and argues for incremental constitutional drafting, debate and implementation as a means of consciously defusing conflicts. Others, like Miller (2010), Miller and Wallis (2014) and Widner (2008) considered the domestic and international credibility that new constitutions afford governing regimes and their institutions. These normsbased sociological arguments may have merit, although confirming them would require broader, more macro-level coding of civil conflict contexts as well as understanding micro-level constitutional texts and processes

But we do know now that some of these more micro-level variables do matter, and they are more discrete and thus easier for scholars and practitioners to measure and implement. The statistical significance we found even at this micro-level does show that inclusion of different societal groups and interests in the process of writing their constitutions matters greatly. Less relevant is exactly what these groups design; as long as they are present in that "smoke-filled room," the constitutional design they draft will have a high probability of diminishing conflict. Group rights are also an important part of the story, as we believe that the inclusion of these, regardless of other components of the process, indicate that inclusion was genuine, as group rights would be a frequent result, and hence a bellwether, of effective inclusion. ${ }^{9}$ Inclusive participation, such as in most of Ecuador's process (at least early on) but not Yemen's, leads to conflict mitigation through the intervening mechanism of group rights establishment, which is much more likely when society's main groups participate in the establishment of a new constitution. Practitioners could benefit by creating more flexible dialogue spaces which offer more concessions to bring boycott-threateners back to the table (and helping facilitate whatever

\footnotetext{
${ }^{9}$ In our sample of 195 national constitutions, we have zero cases with inclusion but without group rights, indicating that if a process is genuinely inclusive, the outcome documents will definitely guarantee groups rights.
} 
concessions are needed to ensure this) and insist that discussion coalesces, in part, around group rights guarantees. Practitioners should worry about getting all actors into the room where the document is drafted; the rest will follow.

Research indicates that, as a generation of political scientists have found before us, the effectiveness of consensus institutions, while normatively appealing, is not demonstrated with regards to the diminishment of conflict upon implementation of new constitutions. As stated by one practitioner, without the "silver bullet" of institutional arrangements for the international community to contribute, what kind of technical advice can be offered $?^{10}$ Our results do directly suggest that convening talks by setting propitious conditions for them would still be a major contribution, as would helping broker information and process transparency. Furthermore, as stated by other practitioners, further research is needed on the role of constitutions within broader peace processes. ${ }^{11}$ It may be that even if the institutional arrangements for power-sharing are not pre-conditions for diminishment of conflict, a "power-sharing mindset" among incumbent elites is necessary to achieve the inclusion needed for conflict-reducing constitutions to move forward. Power-sharing in the process, by bringing all parties to the table, is critical. The resultant language, and whether power-sharing institutions result, is less so.

Further research may be needed to ascertain whether such a mindset of inclusion helps bring about moments propitious for negotiating group rights language in new constitutions, which may be the bellwether of conflict mitigation. But unless and until constitutions are documented as part of broader efforts that include power-sharing as a process, institutional arrangements seem to fall

\footnotetext{
10 The authors thank Helene Grandvionnet, Lead Governance Specialist at The World Bank's Governance Global Practice for this observation at a March 19, 2019 presentation convened by The World Bank's Middle East and North Africa (MENA) Chief Economist.

${ }^{11}$ This was raised by several negotiators, including Abdallah Al Dardari, MENA Senior Adviser on Reconstruction at The World Bank and Susan Stigant, Africa Program Director of the United States Institute of Peace.
} 
short. But what the text says about these institutions and the degree of power-sharing in their configuration does matters less than whether a consensus existed to forge them into text at all.

\section{References}

Acosta, Alberto. 2015. First Chair of the Ecuador Constituent Assembly of 2007. Interview on August 15 in Quito.

Alesina, Alberto, Arnaud Devleeschauwer, William Easterly, Sergio Kurlat, and Romain Wacziarg. 2003. "Fractionalization". Journal Of Economic Growth 8: 155-94.

Alley, April Longley. 2013. "Yemen Changes Everything... And Nothing." Journal Of Democracy 24 (4): 74-85.

Banks, Taunya Lovell. 2001. "What Is A Community? Group Rights And The Constitution: The Special Case Of African Americans." University Of Maryland Law Journal Of Race, Religion, Gender And Class 1 (1): 51-81.

Banks, Arthur S., and Kenneth Wilson. 2016. Cross-National Time-Series Data Archive. Databanks International. Jerusalem, Israel.

Baron, Reuben M., and David A. Kenny. 1986. "The Moderator-Mediator Variable Distinction In Social Psychological Research: Conceptual, Strategic, And Statistical Considerations." Journal Of Personality And Social Psychology 51 (6): 1173-1182.

Becker, Marc. 2010. "Correa, Indigenous Movements, And The Writing Of A New Constitution In Ecuador." Latin American Perspectives 38 (1): 47-62.

Brown, Nathan. 2017. "Islam And Constitutionalism In The Arab World: The Puzzling Course Of Islamic Inflation.". In Constitution Making, Religion And Democracy, eds. Asli Bali and Hanna Lerner. Cambridge: Cambridge University Press. 
Carey, John. 2009. “Does it Matter how a Constitution is Created?" In Is Democracy Exportable, eds. Zoltan Barany and Robert G. Moser. Cambridge University Press, p. 155-177.

Coppedge, Michael, John Gerring, Staffan Lindberg, Svend-Erik Skaaning, Jan Teorell, David Altman, Michael Bernhard, M. Steven Fish, Adam Glynn, Allen Hicken, Carl Henrik Knutsen, Kyle L. Marquardt, Kelly McMann, Valeriya Mechkova, Pamela Paxton, Daniel Pemstein, Brigitte Seim, Rachel Sigman, and Jeffrey Staton. 2017. "V-Dem Codebook v7.1." Varieties of Democracy (V-Dem) Project.

Cruz, Cesi, Philip Keefer, and Carlos Scartascini. 2018. "Database of Political Institutions 2017 (DPI2017)” Inter-American Development Bank. Numbers for Development. https://mydata.iadb.org/Reform-Modernization-of-the-State/Database-of-PoliticalInstitutions-2017/938i-s2bw

Eisenstadt, Todd A., and Tofigh Maboudi. 2019. "Being There is Half the Battle: Group Inclusion, Constitution-Writing, And Democracy." Comparative Political Studies 52 (1314): 2135-2170.

Eisenstadt, Todd, A.Carl LeVan, and Tofigh Maboudi. 2017. Constituents Before Assembly. Cambridge University Press.

Elkins, Zachary, Tom Ginsburg, and James Melton. 2014. Characteristics of National Constitutions, Version 2.0. Comparative Constitutions Project. http://www.comparativeconstitutionsproject.org/index.htm.

Encarnación, Omar. 2005. "Do Political Pacts Freeze Democracy? Spanish And South American Lessons". West European Politics 28 (1): 182-203. 
Fruhstorfer, Anna, and Alexander Hudson. 2019. "Participatory Constitution Making And The Protection Of Minority Rights." Paper presented at the American Political Science Association Annual Meeting, Washington, DC, 2019.

Galenkamp, Marlies. 1993. Individualism And Collectivism: The Concept Of Collective Rights. . Rotterdam: Rotterdamse Filosofische Studies.

Gates, Scott, Benjamin A. T. Graham, Yonatan Lupu, Havard Strand, and Kaare Strom. 2016. "Powersharing, Protection, And Peace". Journal Of Politics 78 (2): 512-26.

Ginsburg, Tom, Zachary Elkins, and James Blout. 2009. "Does the Process of ConstitutionMaking Matter?” Annual Review of Law and Social Science 5 (1): 201-23.

Graham, Benjamin, Michael Miller, and Kaare Strøm. 2017. "Safeguarding Democracy: Powersharing And Democratic Survival". American Political Science Review 111 (4): 686-704.

Gunzler, Douglas, Chen Tian, Pan Wu, and Hui Zhang. 2013. "Introduction To Mediation Analysis With Structural Equation Modeling.". Shanghai Archives Of Psychiatry 25 (6): 390-394.

Hartzell, Caroline A., and Matthew Hoddie. 2015. "The Art Of The Possible: Power Sharing And Post-Civil War Democracy". World Politics 67 (1): 37-71.

Horowitz, Donald L. 1985. Ethnic Groups In Conflict. Berkeley: University of California Press. Horowitz, Donald L. 1991. A Democratic South Africa? Constitutional Engineering In A Divided Society.. Berkeley: University of California Press.

Horowitz, Donald L. 2013. Constitutional Change And Democracy In Indonesia, Problems Of International Politics.. Cambridge [England]: Cambridge University Press. 
Hudson, Alexander. 2019. "Public Participation in Constitution Making: Legitimation, Distraction, and Mass-Elite Interaction." Paper presented at the American Political Science Association Annual Meeting. Washington, DC, 2019.

Human Rights Watch. 2018. “South Sudan: Events of 2017.” https://www.hrw.org/worldreport/2018/country-chapters/south-sudan

Johnson, Darin E.W. 2017. "Conflict Constitution-Making In Libya And Yemen". Upenn Journal Of Intl Law 39 (62).

Jones, Peter. 1999. "Human Rights, Group Rights, And Peoples' Rights." Human Rights Quarterly 21 (1): 80-107.

Keobeble, Thomas, and Andrew Reynolds. 1996. "Power-Sharing Democracy In The New South Africa." Politics \& Society 24 (3): 221-236.

Law, David S., and Mila Versteeg. 2011. "The Evolution And Ideology Of Global Constitutionalism." California Law Review 99 (5): 1163-1257.

Lerner, Hanna. 2011. Making Constitutions In Deeply Divided Societies. New York: Cambridge University Press.

Lerner, Natan. 2003. Group Rights And Discrimination In International Law. Norwell, MA: Kluwer Law International.

Lijphart, Arend. 1996. "The Puzzle Of Indian Democracy: A Consociational Interpretation." American Political Science Review 90 (2): 258-268.

Lijphart, Arend. 2012. Patterns Of Democracy: Government Forms And Performance In ThirtySix Countries. 2nd ed. New Haven: Yale University Press.

Lijphart, Arend. 1977. Democracy In Plural Societies: A Comparative Exploration. New Haven: Yale University Press. 
Linz, Juan. 1990. "The Perils Of Presidentialism." Journal Of Democracy 1 (1): 51-69.

McDonald, Michael. 1991. "Should Communities Have Rights? Reflections On Liberal Individualism". Canadian Journal Of Law \& Jurisprudence 4 (2): 217-237.

McGarry, John, and Brendan O'Leary. 2007. "Iraq's Constitution Of 2005: Liberal Consociation As Political Prescription." International Journal Of Constitutional Law 5 (4): 670-698.

McGarry, John, and Brendan O'Leary. 2004. The Northern Ireland Conflict: Consociational Engagements. Oxford, UK: Oxford University Press.

Miller, Laura E. 2010. Framing The State In Times Of Transition: Case Studies In Constitution Making. Washington, D.C.: United States Institute of Peace Press.

Mujais, Ayat. 2017. "The Dos And Don'Ts Of Federal Constitutions: A Case Study On Yemen." American University International Law Review 33 (1): 287-309.

Newman, Dwight G. 2011. Community And Collective Rights: A Theoretical Framework For Rights Held By Groups. Oxford: Hart Publishing.

Norris, Pippa. 2008. Driving Democracy: Do Power-Sharing Institutions Work? New York, NY: Cambridge University Press.

Pogge, Thomas. 1997. "Group Rights And Ethnicity." Nomos 39: 187-221.

Reilly, Benjamin. 2002. Democracy In Divided Societies: Electoral Engineering For Conflict Management.. New York: Cambridge University Press.

Saati, Abrak. 2015. The Participation Myth: Outcomes Of Participatory Constitution Building Processes On Democracy. Umeå, Sweden: Umeå University.

Salamey, Imad. 2009. "Failing Consociationalism In Lebanon And Integrative Options." Journal Of Peace Studies 14 (2): 83-105. 
Selway, Joel, and Kharis Templeman. 2012. "The Myth Of Consociationalism? Conflict Reduction In Divided Societies." Comparative Political Studies 45 (12): 1542-1571.

Sisk, Timothy. 2017. Democratization In South Africa. Princeton: Princeton University Press. Specia, Megan. 2018. "Estimated Death Toll In South Sudan'S War." New York Times, 2018. https://www.nytimes.com/2018/09/26/world/africa/south-sudan-civil-war-deaths.html.

Sriram, Chandra Lekha, and Marie-Joëlle Zahar. 2010. "The Perils of Power-Sharing: Africa And Beyond." Africa Spectrum 44 (3): 11-39.

Tull, Dennis, and Andreas Mehler. 2005. "The Hidden Costs Of Power-Sharing: Reproducing Insurgent Violence In Africa." African Affairs 104 (416): 375-398.

Wallis, Joanne. 2014. Constitution Making During State Building. New York: Cambridge University Press.

Widner, Jennifer. 2008. "Constitution Writing In Post-Conflict Settings: An Overview." William And Mary Law Review 49: 1513-1540.

Wilkinson, Steven Ian. 2000. "India, Consociational Theory, And Ethnic Violence." Asian Survey 40 (5): 767-791.

Williams, Paul, Tiffany Sommadossi, and Ayat Mujais. 2017. "A Legal Perspective On Yemen'S Attempted Transition From A Unitary To A Federal System Of Government." Utrecht Journal Of International And European Law 33 (84): 4-22.

Wing, Susanna. 2008. Constructing Democracy In Transitioning Societies Of Africa. New York: Palgrave Macmillan.

Younis, Nussaibah. 2011. "Set Up To Fail: Consociational Political Structures In Post-War Iraq, 2003-2010." Contemporary Arab Affairs 4 (1): 1-18. 